\title{
Effect of antibiotic ceftriaxone on elimination of ABI and GV3101 strains of Agrobacterium tumefaciens
}

\author{
I. R. Gorbatyuk, I. S. Gnatyuk, M. A. Bannikova \\ Institute of Cell Biology and Genetic Engineering, NAS of Ukraine \\ 148, Akademika Zabolotnogo Str., Kyiv, Ukraine, 03680 \\ molgen@icbge.org.ua, gorbatyuk.irina.90@gmail.com
}

\begin{abstract}
Aim. To find out, at which concentration the antibiotic ceftriaxone of $\beta$-lactam group causes the elimination of ABI and GV3101 strains of Agrobacterium tumefaciens. Methods. The disc diffusion method. Results. Antibiotic ceftriaxone was used for the cell elimination of the Agrobacterium tumefaciens ABI strain for the first time. The same zones of inhibition were observed when using the $400 \mathrm{mg} / \mathrm{l}$ ceftriaxone and $500 \mathrm{mg} / \mathrm{l} \mathrm{ce-}$ fotaxime solutions for both Agrobacterium strains (ABI and GV3101) studied. Conclusions. Ceftriaxone inhibits the Agrobacterium growth more effectively than cefotaxime. The ceftriaxone concentration for elimination of ABI and GV3101 Agrobacterium tumefaciens strains is $400 \mathrm{mg} / \mathrm{l}$.
\end{abstract}

Ke y w o r d s: ceftriaxone, Agrobacterium tumefaciens, elimination

\section{Introduction}

Various Agrobacterium tumefaciens strains mediate the genetic transformation of plants. The antibiotics of $\beta$-lactam group are used for the bacterial cell elimination during Agrobacterium-mediated transformation $[1,2]$. They kill bacteria by specific interfering with biosynthesis of the peptidoglycan component of the bacterial cell wall via binding to Penicillin-Binding Proteins (PBPs) whereas there is only little or no detrimental effect on the eukaryotic plant cells [3-5]. The antibiotics cefotaxime and carbenicillin are commonly used for the Agrobacterium cell elimination. Nowadays the usage of carbenicillin becomes undesirable because of its toxicity. Cefotaxime is mostly used in concentrations of 500 $\mathrm{mg} / \mathrm{l}$ and higher [6]. However, the numerous studies prove the negative effect of its high concentrations on the organogenesis, embryogenesis and shoot regeneration of most plant species [4]. Now, timentin and ceftriaxone ( $\beta$-lactam group) are frequently used instead of cefotaxime [7, 8]. These antibiotics eliminate $A$. tumefaciens efficiently during the genetic transformation in vitro and do not affect the regeneration frequency in most cases. Thus, ceftriaxone may be considered as an alternative to cefotaxime.

Ceftriaxone, a third-generation cephalosporin, characterized by a prolonged half-value period, has the broad-spectrum activity. The successful elimination of various Agrobacterium tumefaciens strains (EHA105, LBA4404, AGL_1) by means of ceftriaxone has been earlier reported [9-13]. However, it has not been yet used for the elimination of ABI Agrobacterium strain.

The aim of our study was to find out the concentration of ceftriaxone, the antibiotic of $\beta$-lactam group, causing the eliminating effect on the $\mathrm{ABI}$ and GV3101 strains of Agrobacterium tumefaciens.

\section{Materials and Methods}

The ceftriaxone effect on the ABI and GV3101 Agrobacterium tumefaciens strains was evaluated by

(C) 2015 I. R. Gorbatyuk et al.; Published by the Institute of Molecular Biology and Genetics, NAS of Ukraine on behalf of Biopolymers and Cell. This is an Open Access article distributed under the terms of the Creative Commons Attribution License (http://creativecommons.org/licenses/by/4.0/), which permits unrestricted reuse, distribution, and reproduction in any medium, provided the original work is properly cited 
disk diffusion method [13]. Cefotaxime (500 mg/l) was used as a control. We also compared the eliminating capability of ceftriaxone and timentin. Agrobacterium night culture was sown on Himedia M001 (LB analog) agar medium [14]. The earlier sterilized paper disks (6 mm diameter) were moistened by antibiotic solutions (ceftriaxone: $300 \mathrm{mg} / \mathrm{l}$, $350 \mathrm{mg} / 1,400 \mathrm{mg} / 1,450 \mathrm{mg} / 1,500 \mathrm{mg} / \mathrm{l}$; timentin: $100 \mathrm{mg} / 1,150 \mathrm{mg} / 1,200 \mathrm{mg} / 1,250 \mathrm{mg} / 1,300 \mathrm{mg} / 1$, $350 \mathrm{mg} / \mathrm{l}, 400 \mathrm{mg} / \mathrm{l}$ ) and put on the medium surface. Bacterial cultures were $\left(\mathrm{OD}_{600}=0.8\right)$ cultivated in thermostat at $27{ }^{\circ} \mathrm{C}$ during 48 hours. Linear measurement of the inhibition zone diameter was carried out during 48-hour period. The experiment was repeated three times.

\section{Results and Discussion}

The inhibiting effects of ceftriaxone, cefotaxime and timentin on the cells of ABI and GV3101 Agrobacterium tumefaciens strains were compared in our study.

The ceftriaxone concentrations used by Chinese investigators for elimination of various Agrobacterium strains were as follows: $200 \mathrm{mg} / \mathrm{l}$ or $500 \mathrm{mg} / \mathrm{l}$ for LBA4404 [4]; $200 \mathrm{mg} / 1$ or $500 \mathrm{mg} / 1$ for EHA105 [12]; $300 \mathrm{mg} / 1$ for AGL_1 [11]; 300, 400 or $500 \mathrm{mg} / 1$ for GV3101 [9] in case of genetic transformation of various plant species. Ceftriaxone in all the studied

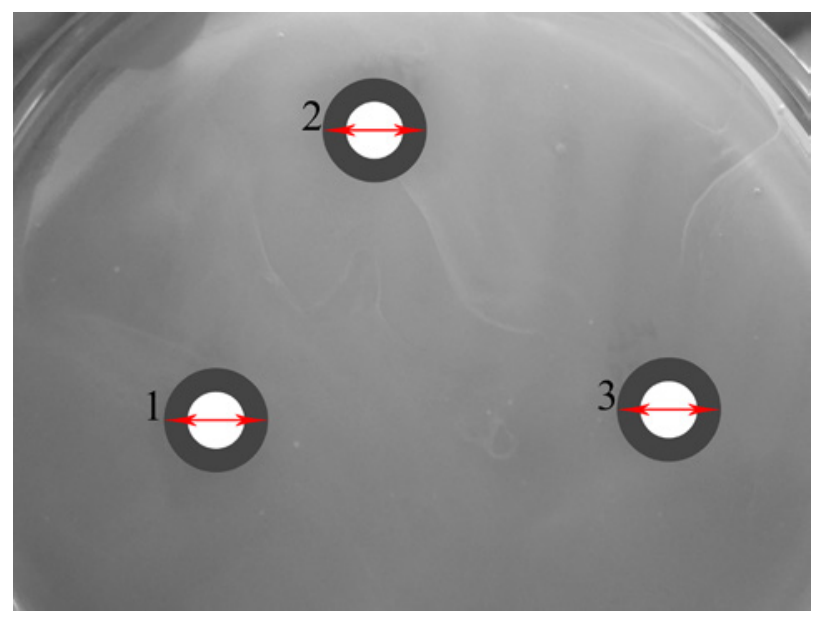

Fig. 1. Zones of ABI Agrobacterium tumefaciens strain inhibition by the studied antibiotics: $1.400 \mathrm{mg} / \mathrm{l}$ ceftriaxone; 2. $500 \mathrm{mg} / \mathrm{l}$ cefotaxime; $3.350 \mathrm{mg} / \mathrm{l}$ timentin. concentrations was proved to eliminate the bacterium growth. Timentin was also used for bacteria elimination: $250 \mathrm{mg} / 1$ [13] or $400 \mathrm{mg} / \mathrm{l}$ [15] for EHA105 strain, $250 \mathrm{mg} / 1$ for C58 strain [7], $150 \mathrm{mg} / 1$ [16] or $400 \mathrm{mg} / 1$ [17] for LBA4404 strain, $50 \mathrm{mg} / 1$ for KYRT1strain [18]; $400 \mathrm{mg} / 1$ for GV3101 strain [12]. Cefotaxime $(500 \mathrm{mg} / \mathrm{l})$ is commonly used for elimination of most mentioned strains.

The suppression zone of $12.5 \mathrm{~mm}$ diameter was shown for ABI strain in case of using the solutions: $400 \mathrm{mg} / \mathrm{l}$ ceftriaxone, $500 \mathrm{mg} / \mathrm{l}$ cefotaxime and 350 $\mathrm{mg} / \mathrm{l}$ timentin (Fig. 1). The inhibiting zone was 10.5 $\mathrm{mm}$ in case of using the mentioned concentrations of antibiotics for GV3101 strain. This way, ceftriaxone was proved to inhibit the Agrobacterium growth more effectively than cefotaxime and less effectively than timentin. We consider that ceftriaxone should be used in the concentration of $400 \mathrm{mg} / \mathrm{l}$ for elimination of the GV3101 Agrobacterium strain.

\section{Conclusions}

Ceftriaxone has been shown to inhibit the Agrobacterium growth more effectively comparing to the cefotaxime effect: the zones of inhibition were proved to be of the same size in cases of using the $400 \mathrm{mg} / \mathrm{l}$ ceftriaxone and $500 \mathrm{mg} / \mathrm{l}$ cefotaxime solutions for both studied Agrobacterium strains (ABI and GV3101).

\section{REFERENCES}

1. Demain $A L$, Elander RP. The beta-lactam antibiotics: past, present, and future. Antonie Van Leeuwenhoek. 1999;75(12):5-19.

2. Tran TN, Sanan-Mishra N. Effect of antibiotics on callus regeneration during transformation of IR 64 rice. Biotechnol Rep. 2015;7:143-9.

3. Asbel LE, Levison ME. Cephalosporins, carbapenems, and monobactams. Infect Dis Clin North Am. 2000;14(2):43547.

4. Yarizade A, Aram F, Niazi A, Ghasemi Y. Evaluation of effect of $\beta$-lactam antibiotics on suppression of different strains of Agrobacterium tumefaciens and on wheat mature embryo culture. Iran J Pharm Sci. 2012; 8(4):267-76.

5. Farzaneh A, Adel $Y$, Ali $N$, Younes $G$. Determine effective concentrations of $\beta$-lactam antibiotics against three strains of Agrobacterium tumefaciens and phytotoxicity on Tomato and Tobacco. Int J Agron Plant Prod. 2013;4 (11):2919-25 
6. Dubrovna OV, Morgun BV, Bavol AV. Wheat Biotechnology: cell selection and genetic engineering. K.: Logos, 2014. $375 \mathrm{p}$.

7. Tang H, Ren Z, Krczal G. An evaluation of antibiotics for the elimination of Agrobacterium tumefaciens from walnut of somatic embryos and for the effects on the proliferation of somatic embryos and regeneration of transgenic plants. Plant Cell Rep. 2000;19(9):881-7.

8. Grzebelus E, Skop L. Effect of $\beta$-lactam antibiotics on plant regeneration in carrot protoplast cultures. In Vitro Cell Dev Biol Plant. 2014;50(5):568-575.

9. Fallah-Ziarani M, Haddad R, Garoosi Gh, Jalali M. Agrobacterium-mediated transformation of cotyledonary leaf of lettuce (Lactuca sativa L.) by the GCHI gene. Iran J Gen Plant Breed. 2013;2(2): 47-55.

10. Zhao $X$, Zhan L-P, Zou $X$-Z. Improvement of cold tolerance of the half-high bush Northland blueberry by transformation with the LEA gene from Tamarix androssowii. Plant Growth Regul. 2011; 63(1):13-22

11. Ji Y-R,Liu W-W,Guan X-J,Hou H-Y. Effects of antibiotics on Agrobacterium strain AGL_1 and differentiation rate of adventitious buds from hypocotyls of Fibre Flax. Plant Fiber Sci China. 2008; 30.

12. LI Wei-huan et al. Establishment of the genetic transformation system of Limonium sinense mediated by Agrobacterium tumefaciens. Journal of Anhui Agricultural Sciences. 2008; 7.

13. Priya A, Pandian SK, Manikandan $R$. The effect of different antibiotics on the elimination of Agrobacterium and high frequency Agrobacterium-mediated transformation of indica rice (Oryza sativa L.). Czech J Genet Plant Breed. 2012; 48(3): $120-30$

14. Bertani $G$. Studies on lysogenesis. I. The mode of phage liberation by lysogenic Escherichia coli. J Bacteriol. 1951;62(3):293-300.

15. Palla KJ, Pijut PM. Agrobacterium-mediated genetic transformation of Fraxinus americana hypocotyls. Plant Cell Tissue Organ Cult. 2015; 120(2): 631-41.

16. Ling $H-Q$, Kriseleit D, Ganal $M W$. Effect of ticarcillin/potassium clavulanate on callus growth and shoot regeneration in Agrobacterium-mediated transformation of tomato (Lycopersicon esculentum Mill.). Plant Cell Rep. 1998; 17(11):843-47.

17. Mamidala $P$, Nanna $R$. Influence of antibiotics on regeneration efficiency in tomato. Plant Omics J. 2009; 2(4):135-40.
18. Han $S-N$, Oh P-R, Kim H-S, Heo H-Y, Moon JC, Lee $S-K$, Kim K-H, Seo $Y-W$, Le B-Me. Effects of antibiotics on suppression of Agrobacterium tumefaciens and plant regeneration from wheat embryo. J Crop Sci Biotech. 2007; 10 (2):92-8.

Ефект антибіотика цефтриаксона на елімінацію Agrobacterium tumefaciens штаммів ABI та GV3101

I. Р. Горбатюк, I. С. Гнатюк, М. О. Банникова

Мета. 3'ясувати за якої концентрації антибіотик цефтриаксон з групи $\beta$-лактамів викликає елімінацію штамів ABI та GV3101 Agrobacterium tumefaciens. Методи. Метод дифузії з дисків. Результати. Для елімінації клітин Agrobacterium tumefaciens штаму ABI антибіотик цефтриаксон використано вперше. Для обох досліджуваних штамів агробактерії (ABI та GV3101) спостерігалися однакові зони ігібування за використання розчину 400 мг/л цефтриаксону та 500 мг/л цефотаксиму. Висновки. Цефтриаксон пригнічує ріст агробактерій більш ефективно, ніж цефотаксим. Концентрація цефтриаксону для еліміннації штамів ABI та GV3101 Agrobacterium tumefaciens - 400 мг/л.

Кл юч о в і с л о в а: цефтриаксон, Agrobacterium tumefaciens, елімінація

\section{Эффект антибиотика цефтриаксона на элиминацию Agrobacterium tumefaciens штаммов АВI и GV3101}

И. Р. Горбатюк, И. С. Гнатюк, М. А. Банникова

Цель. Выяснить при какой концентрации антибиотик цефтриаксон из группы $\beta$-лактамов вызывает элиминацию штаммов ABI и GV3101 Agrobacterium tumefaciens. Методы. Метод диффузии из дисков. Результаты. Для элиминации клеток Agrobacterium tumefaciens штамма ABI антибиотик цефтриаксон использован впервые. Для обоих изучаемых штаммов агробактерии (ABI и GV3101) наблюдались одинаковые зоны ингибирования при использовании раствора 400 мг/л цефтриаксона и 500 мг/л цефотаксима. Выводы. Цефтриаксон ингибирует рост агробактерий более эффективно, чем цефотаксим. Концентрация цефтриаксона для элиминации штамов ABI и GV3101 Agrobacterium tumefaciens - 400 мг/л.

Кл ючевы е слов а: цефтриаксон, Agrobacterium tumefaciens, элиминация

Received 10.10.2015 